\title{
Life History, Growth, and Reproductive Biology of Four Mobulid Species in the Bohol Sea, Philippines
}

Joshua M. Rambahiniarison ${ }^{1 *}$, Mary Jane Lamoste ${ }^{1}$, Christoph A. Rohner ${ }^{2}$, Ryan Murray ${ }^{1}$,
Sally Snow ${ }^{1}$, Jessica Labaja ${ }^{1}$, Gonzalo Araujo ${ }^{1}$ and Alessandro Ponzo ${ }^{1}$ ${ }^{1}$ Large Marine Vertebrates Research Institute Philippines, Bohol, Philippines, ${ }^{2}$ Marine Megafauna Foundation, Inhambane, Mozambique

In light of the global decline of mobulid populations and the necessity for sustainable fisheries management, baseline data for population dynamics were collected from a targeted fishery in the Bohol Sea, Philippines. This study focused on life-history parameters and reproductive cycles of four mobulid rays (Mobula thurstoni, Mobula japanica, Mobula tarapacana, and Manta birostris), and re-estimated their intrinsic population growth rates. Size and reproductive data were collected from 1,509 specimens (30\% of catch) landed in two fishing seasons in 2015 and 2016. Size-at-birth was reviewed, and analysis of the embryos and follicles did not show any clear seasonality in the reproductive cycle, but supported an interbreeding interval. Females of all species matured at a larger size than males, and exhibited a larger size-at-pregnancy than -at-maturity. This delay in reproduction resulted in population growth rates lower than the actual $r_{\max }$ when based on size-at-pregnancy $\left(r_{\operatorname{mat}}=r_{\max }=0.016-0.055\right.$ year $^{-1}$ and $r_{\text {preg }}=0.008-0.044$ year $^{-1}$ ), and a population doubling time of 15.8-86.6 years. This study suggests that population growth rates previously reported were overestimated. In light of the Convention on International Trades of Endangered Species (CITES) and Convention on Migratory Species (CMS) assessments, while fisheries management should reflect the delayed maturation of these species and the slower population growth potential, at the current status of these population, the sustainability of any exploitation level seems unrealistic and strongly discouraged.

Keywords: elasmobranchs, sexual maturity, reproduction, intrinsic growth rate, population doubling time

\section{INTRODUCTION}

Many shark and ray species have conservative life-history parameters (i.e., late maturation, low fecundity; Cortés, 2000, 2002; Dulvy et al., 2008, 2014a), and are therefore unlikely to sustain high levels of fishing pressure (Stevens et al., 2000; Dulvy et al., 2008). Clear evidence of this is the local and global decline of elasmobranch populations (Dulvy et al., 2014a). Managing elasmobranch fisheries is restricted for many species by the lack of available data on catch, effort, landings and trade, as well as limited information on biological parameters. Demographic data are needed to assess the impacts of fisheries (Cortés, 2002; Musick and Bonfil, 2004; Dulvy et al., 2014b; Simpfendorfer and Wetherbee, 2015), but are largely lacking for most devil rays (Chondrichthyes: Mobulidae). 
Available demographic data on mobulid species suggest that the reef manta ray Manta alfredi Krefft 1868 (Dulvy et al., 2014b) and the spine tail devil ray Mobula japanica Müller and Henle, 1841 (Pardo et al., 2016a) have one of the lowest population growth rates amongst studied elasmobranchs (Dulvy et al., 2014b). Mobulids give birth to single, large and less vulnerable offspring per litter after an estimated gestation period of 1 year (Notarbartolo-Di-Sciara, 1988; Marshall and Bennett, 2010), with a pregnancy interval of 2-5 years (Homma et al., 1997; Marshall and Bennett, 2010; Croll et al., 2015). Life history traits such as size-at-maturity were estimated from free-living individuals for Manta alfredi from Mozambique (Marshall et al., 2011a) and Hawaii (Clark, 2010). In location such as Indonesia (White et al., 2006b) and the Gulf of California (NotarbartoloDi-Sciara, 1988), the difficulty to assess female sexual maturity from specimens landed eviscerated or in an advanced state of decomposition resulted mainly in the description of male parameters for the bent fins devil ray Mobula thurstoni Lloyd 1908 and the sickle fin devil ray Mobula tarapacana Philippi, 1892. Our study therefore focuses on female parameters to understand the size-at-pregnancy and the reproductive cycle for $M$. thurstoni, M. japanica, $M$. tarapacana, and the oceanic manta ray Manta birostris Walbaum, 1792, considering its importance to estimate the reproductive potential within a population (Mollet and Cailliet, 2002; Musick and Bonfil, 2004).

Mobulid populations face heavy exploitation across their whole geographical range from tropical to warm temperate waters (Couturier et al., 2012; Croll et al., 2015) for both meat consumption and to supply a large international trade for their gill rakers (Dulvy et al., 2014a; Croll et al., 2015). Given the rise in their exploitation and reported population decline (Dulvy et al., 2014a; Croll et al., 2015), all Mobulidae have been listed on the Convention on International Trades of Endangered Species of wild fauna and flora (CITES) Appendix II and the Convention on the Conservation of Migratory Species of wild animals (CMS) Appendices I and II between 2011 and 2016. This listing has been locally supported and implemented in the Philippines by the new Republic Act No. 10654 amending the Philippine Fisheries Code of 1998 prohibiting the catch, possession and trade of aquatic species listed under CITES Appendices (Republic of the Philippines, 2015).

In the Bohol Sea, Philippines, direct fisheries have exploited mobulids for local consumption and gill rakers export for over a century (Fowler et al., 2002; Rayos et al., 2012; Acebes and Tull, 2016), and are now banned since April 2017 after the implementation of the CITES listing. In the municipality of Jagna, in the south-east of the island of Bohol, industrialization of the fishing fleet in the 1970's transformed a traditional coastal sailing harpoon-based fishery into a motorized offshore driftnet practice (Acebes and Tull, 2016). A monitoring program of this fishery revealed that over 2,000 individuals were landed per season (Authors, unpub data). The fishing season for mobulids coincided with the northeast monsoon when increased upwelling leads to higher primary productivity in surface waters (Cabrera et al., 2011; Gordon et al., 2011), with prolific pulses of krill Euphausia diomedeae on which mobulids feed in the area (Rohner et al., 2017; Stewart et al., 2017). The four species studied here were caught with drift nets, a targeted but not selective fishing gear, resulting in the catch of $M$. birostris despite it being protected nationally since 1998 (Fisheries Administrative Order 193; Republic of the Philippines., 1998), and other elasmobranchs, such as thresher shark Alopias spp., juvenile silky sharks Carcharhinus falciformis, and large bony fishes such as billfishes.

The present outputs aim to provide information and biological parameters as basis for population dynamics, and inputs for quantitative population assessments. Life history traits were investigated as was the reproductive cycle of four mobulids in the Bohol Sea, based on measurements and morphological assessments of their fresh reproductive organs. This study provides weight-at-width relationship, quantifies the size-atbirth, -at-maturity and -at-pregnancy, and examines the fetussize distribution and ovarian follicles development throughout the season. Despite the recent updated taxonomic arrangement for the family Mobulidae resulting in a single genus Mobula as well as the inclusion of M. japanica as M. mobular (White et al., 2017), the authors decided to keep the previous nomenclature for $M$. birostris to facilitate advices to the local government, considering the laws already in place. It was also decided to keep the nomenclature of $M$. japanica, following Bustamante et al. (2015).

\section{METHODS}

\section{Study Site and Fishery}

Mobulid fishery monitoring was conducted daily at the landing site of Barangay Bunga Mar in the municipality of Jagna $\left(9^{\circ} 38^{\prime} 29^{\prime \prime} \mathrm{N} ; 124^{\circ} 22^{\prime} 52^{\prime \prime} \mathrm{E}\right)$, Philippines (Figure 1), from February to June 2015 and from November 2015 to May 2016. The Bohol Sea is known as the main fishing ground for mobulids in the country, and Bunga Mar its largest landing port, making an ideal study site for these species. The fishing season lasts from November to June. This targeted fishery was composed of 1-12 mobulid fishing boats traveling daily up to $60 \mathrm{~km}$ offshore within the Bohol Sea (Figure 1). Each of them used a drift net between $1-1.5 \mathrm{~km}$ in length and $30 \mathrm{~m}$ in height, fishing at night between 10 and $40 \mathrm{~m}$ depth, for a soak time of $\sim 8 \mathrm{~h}$, and returning to the landing site in the early morning. Ninety-six percent of all specimens ( $n=1,448$ of 1,509) analyzed here were caught by these boats targeting mobulids, and an additional 61 (4\%) specimens included in the dataset came from occasional by-catch from tuna fishing boats operating in the same area. Mobulids brought to shore were freshly dead or occasionally still alive.

\section{Sampling}

All data were collected at the landing site on the shoreline of Bunga Mar, Jagna, Bohol. Fishers and buyers allowed access to the landed specimens as they were being prepared and sold to be processed locally or transported to other towns. In the first season, 402 specimens were randomly measured among the specimens landed $(>2,000)$, and a subset of 179 rays was assessed for reproductive biology (i.e., sex, sexual maturity, pregnancy). In the second season, all specimens landed were counted and the sex was determined for $80 \%$ of the total catch $(n=2,219)$. All 


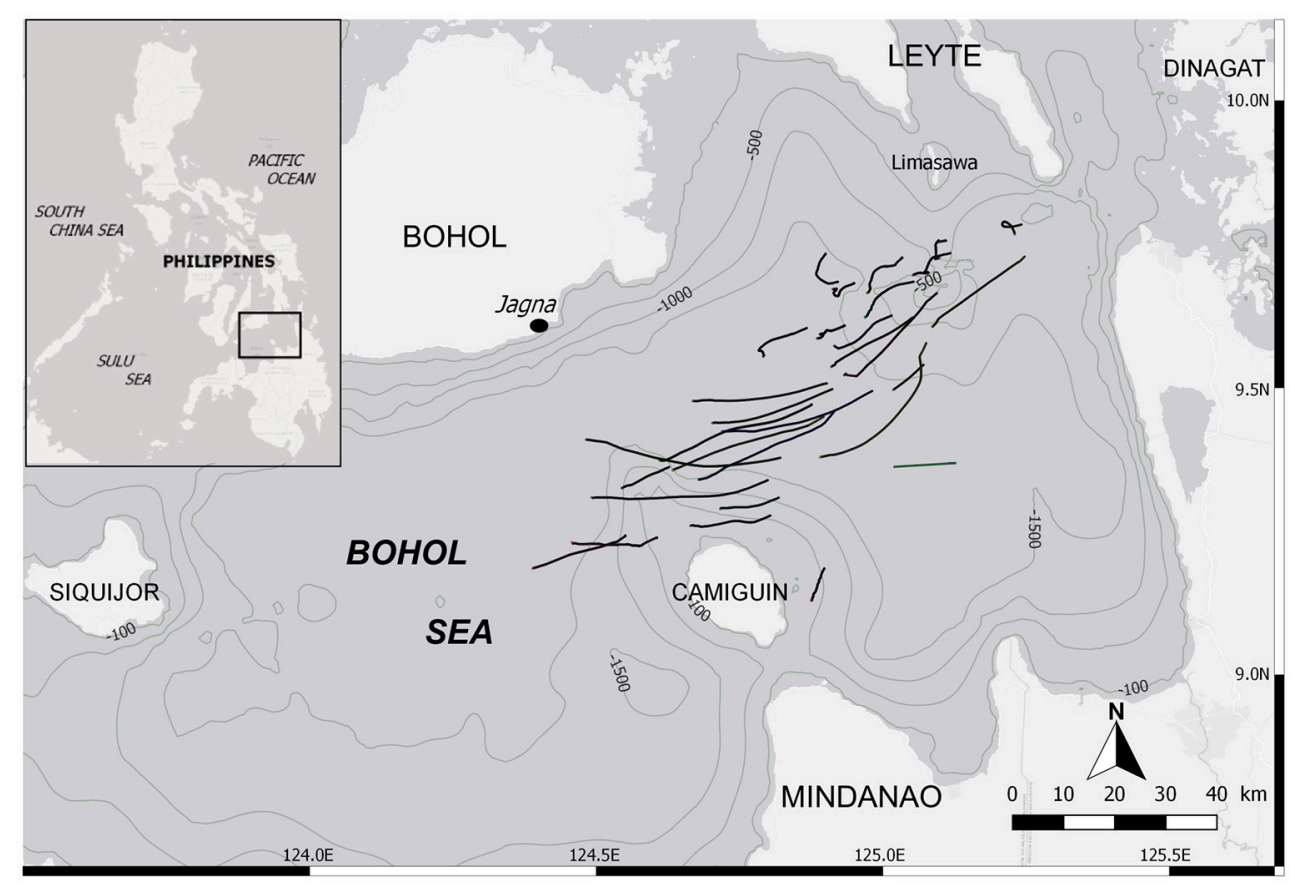

FIGURE 1 | Location of the landing site and the fishing grounds within the Bohol Sea, Philippines. Black lines depict tracks from mobulid fishing boats while their drift net was deployed $(n=30)$. It is not exhaustive, but indicative of the fishing grounds.

identified females $(100 \%, n=1,069)$ were assessed for pregnancy. The tail and pelvic fins of rays were cut most of the time by the fishers before landing, thus sex was confirmed based on inspection of the internal organs. Species were identified using identification keys adapted from Compagno and Last (1999) and Stevens (2011). Out of over 4,000 specimens landed in the two seasons, 1,509 individuals from four species were examined and included in the present analysis, respectively $M$. thurstoni $(n=817,54 \%), M$. japanica $(n=450,30 \%), M$. birostris $(n=173,11 \%)$, and M. tarapacana $(n=69,5 \%)$.

\section{Disc Width and Body Weight}

Disc width was recorded in centimeters (DW, precision $=0.2 \mathrm{~cm}$ ) using a measuring tape in a straight line across the dorsal side when the animal was lying flat, intact, on its ventral side, following Notarbartolo-Di-Sciara (1987). As different researchers were involved in this study, we compared the DW measurements collected by three random researchers for 64 specimens, and found no significant difference between researchers (Kruskall-Wallis, $d f=2, P>0.05$ ). Therefore, the observer variability was excluded from any further analysis. The maximal size of each species was taken from the literature for M. japanica (250 cm DW) (White et al., 2006a), M. tarapacana (328 cm DW) (Pardo et al., 2016c), M. birostris $(700 \mathrm{~cm} \mathrm{DW})$ (Marshall et al., 2011b), and from the present study for $M$. thurstoni $(197 \mathrm{~cm} \mathrm{DW})$ to calculate the percentage of maximal disc width at maturity.

Total body mass was recorded in kilograms (TM, precision $=0.5 \mathrm{~kg}$ ) using a hanging scale for $M$. thurstoni and $M$. japanica. Specimens lighter than seven kilos were weighed using a digital scale (precision $=1.0 \mathrm{~g}$ ). Due to their large size, $M$. birostris could not be weighed and only few $M$. tarapacana $(n=8)$ were weighed in three pieces after the separation of the pectoral fins from the body. The relationship between DW and TM was plotted for M. thurstoni, M. japanica, fetus $M$. birostris, and M. tarapacana, and described by the non-linear model $T M=a D W^{b}$ (Notarbartolo-Di-Sciara, 1988) where $a$ and $b$ were determined by a non-linear least squares estimation. The difference between sexes for this relationship was tested using ANCOVA (covariates: disc width and sex). Statistical analyses were conducted in R 3.3.1.

\section{Reproductive Variables}

To investigate female reproductive variables, ovaries and uteri were immediately assessed and measured from the specimens at the landing site according to criteria adapted from Braccini et al. (2006) and ICES (2013) (Table 1), then sexual maturity was determined as described in section Maturity and Pregnancy Ogives. For M. tarapacana, $82 \%(n=17)$ of the females had epigonal organs liquefied and follicles were partially damaged. This could possibly be due to a longer time under the sun prior to be open as this species was usually sold last, or perhaps a higher sensitivity to stress for this species when being entangled in the net inducing a faster deterioration of the epigonal organs, a lymphoid organ sensitive to stress hormones. Therefore, the maturity assessment of $M$. tarapacana was based solely on the uterus. For all other species, the largest follicle diameter $(\mathrm{LFD}$, precision $=0.1 \mathrm{~cm})$ was measured using a caliper. The 
TABLE 1 | Criteria used to determine the internal maturity stage of the Mobulidae, adapted from Braccini et al. (2006) and ICES (2013).

\begin{tabular}{lll}
\hline & Male & Female \\
\hline -Immature & $\begin{array}{l}\text { Testes with undifferentiated thin } \\
\text { tissue strip, small testicular } \\
\text { lobules. Generally dominated by } \\
\text { epigonal organ } \\
\text { Epididymis begins to coil } \\
\text { Ductus deferent is thread-like }\end{array}$ & $\begin{array}{l}\text { Ovary with indistinguishable } \\
\text { follicles or small sized follicles } \\
\text { Uteri are thin strip-like or } \\
\text { partially enlarged }\end{array}$ \\
\hline -Mature & $\begin{array}{l}\text { Testes are enlarged, highly } \\
\text { lobular and fully developed within } \\
\text { the epigonal organ } \\
\text { Epididymis is highly coiled } \\
\text { Ductus deferent is enlarged }\end{array}$ & $\begin{array}{l}\text { Ovary has large and developed } \\
\text { follicles } \\
\text { Uteri are enlarged and tubular } \\
\text { with well-developed } \\
\text { trophonemata. Embryo or fetus } \\
\text { can be present }\end{array}$ \\
& &
\end{tabular}

reproductive cycle was investigated by plotting the LFD of mature females against the disc width and the calendar month. In addition, pregnancy was assessed for all females from November 2015 to April 2016. Fetuses were collected, even if measurements for the mother were missing prior to being sliced, and the disc widths of fetuses were plotted against the calendar month.

To investigate male reproductive variables, the testes, epididymis, and ductus deferent were immediately assessed and measured according to criteria adapted from Braccini et al. (2006) and ICES (2013) (Table 1), then sexual maturity was determined as described in section Maturity and Pregnancy Ogives. The pelvic fins and claspers of rays were removed most of the time by the fishers previous to landing, thus for consistency, male maturity status was based on internal organs assessment, and the extent of clasper calcification (flexible when none or partially calcified, rigid when fully calcified) was only recorded as additional data.

\section{Maturity and Pregnancy Ogives}

Sexual maturity stage for both sexes was based on visual examination of the reproductive organs according to criteria adapted from Braccini et al. (2006) and ICES (2013) (Table 1), and a binomial maturity status was assigned as zero (immature) or one (mature). Mating scars (Yano et al., 1999) were not assessed because similar abrasions on the pectoral fins also resulted from fishing gear and friction on boats when the specimens were loaded and unloaded from the fishing vessel. The maturity ogives for both males and females were established separately, using a logistic model (Braccini et al., 2006; White et al., 2006b; ICES, 2008; Harry et al., 2013), where population size-at-maturity $\left(\mathrm{DW}_{50}\right)$ was the disc width at which $50 \%$ of the population was mature. Model parameters were estimated using a generalized linear model with a binomial error structure and the maximum likelihood method of the logit-link function. The significance of fitted models was assessed with $\chi^{2}$-tests. Pregnancy was assessed by visual inspection upon opening the uterus. A female was classified as pregnant if an embryo or fetus was present in the uterus or if the uterus had a flaccid and dilated appearance with fully developed trophonemata, resulting from recent delivery or abortion. However, females in an early stage of pregnancy could possibly be carrying an embryo not yet visible to the naked eye and could have been overlooked. Pregnancy status was assigned as zero (non-pregnant) or one (pregnant). The pregnancy ogives were estimated using the same method as above, where the size-at-pregnancy ( $\left.\mathrm{DW}_{50 \text { pregnancy }}\right)$ is the disc width at which $50 \%$ of the female population was pregnant.

\section{Size-at-Birth}

Two hundred and one fetuses were collected from pregnant females when fishers opened them on the beach. Morphometric measurements were recorded following Marshall et al. (2008). For each species, inference of the size-at-birth was based on the disc width of the largest fetus and the smallest free-living specimen landed (Table 2 ). Sex ratio's difference from parity was tested using a $\chi^{2}$-test.

\section{Von Bertalanffy and Population Growth Rate}

Given the life history parameter estimations reported herein, related aged-parameters (i.e., age-at-maturity and -at-pregnancy) and population growth rate were re-estimated for $M$. japanica, M. thurstoni and M. birostris, building on work by CuevasZimbrón et al. (2013), Dulvy et al. (2014b), and Pardo et al. (2016a). A two-step approached was used:

1) Age estimation. Female age-at-maturity and -at-pregnancy for mobulids was determined by using the Von Bertalanffy (VB) growth model following Cuevas-Zimbrón et al. (2013):

$$
D W_{t}=D W_{\infty}\left[1-e^{-k\left(t-t_{0}\right)}\right]
$$

where $D W_{t}$ the disc width at time $t, D W_{\infty}$ the theoretical asymptotic disc width related to the maximal size as $\mathrm{DW}_{\infty}=1.01^{*} \mathrm{DW} W_{\max }, k$ the growth coefficient, and $t_{0}$ the theoretical age at zero length. Due to the lack of size-at-age data for $M$. thurstoni, growth parameter values $k$ and $t_{0}$ were assumed the same as for M. japanica, considering the close growth curves, size range and ecology of these two species (White et al., 2006b; Couturier et al., 2012; present study). Using estimations and various prior values from CuevasZimbrón et al. (2013) and Pardo et al. (2016a), three scenarios were therefore used with both species to calculate their ages. For M. birostris, $k$ was taken from Dulvy et al. (2014b), and $t_{0}$ was similar as the other species above. Age estimations related to their respective parameter values and priors are reported in Table 3. Ages -at-maturity and -at-pregnancy refer to the present respective size-at-maturity and -at-pregnancy. For M. japanica, the estimated size-at-pregnancy $(261.1 \mathrm{~cm}$, se $=17.9, n=8)$ was used when $D W_{\infty}$ was larger $(299.0 \mathrm{~cm}$ for strong prior from Pardo et al. (2016a)). However, the mean size of pregnant females $(223.5 \mathrm{~cm}$, se $=1.5, n=8)$ was used when $D W_{\infty}$ was smaller $[251.5 \mathrm{~cm}$ for weaker prior from Pardo et al. (2016a), and $233.8 \mathrm{~cm}$ for prior from CuevasZimbrón et al. (2013)]. 
TABLE 2 | Summary of life-history traits and reproductive onset for the four mobulids, in this study.

\begin{tabular}{|c|c|c|c|c|}
\hline Species & Mobula thurstoni & Mobula japanica & Manta birostris & Mobula tarapacana \\
\hline \multicolumn{5}{|l|}{ Size range } \\
\hline Male & $90.2-182.0$ & $114.0-235.0$ & $284.0-471.0$ & $164.0-317.0$ \\
\hline Female & $92.0-197.0$ & $99.8-239.0$ & $230.0-554.4$ & 160.0-295.0 \\
\hline \multicolumn{5}{|l|}{ Size-at-maturity $(\mathrm{se}, n)$} \\
\hline Male & $158.4(0.9,106)$ & $205.8(1.6,63)$ & $381.9(8.7,48)$ & $252.1(3.4,19)$ \\
\hline Female & $163.6(0.6,224)$ & $217.8(1.1,77)$ & $448.0(6.9,63)$ & $264.8(6108.9,2)$ \\
\hline Size-at-pregnancy $(\mathrm{se}, n)$ & $171.5(0.8,141)$ & $261.1(17.9,8)$ & $532.9(9.6,20)$ & - \\
\hline Smallest mature female & 146.0 & 204.0 & 402.0 & 271.8 \\
\hline Largest immature female & 169.0 & 227.0 & 479.0 & 258.0 \\
\hline Smallest pregnant & 148.0 & 218.0 & 476.0 & - \\
\hline \multicolumn{5}{|l|}{ Largest follicle diameter } \\
\hline Immature & $0.0-2.4$ & $0.0-2.2$ & $1.4-3.2$ & $0.1-0.9$ \\
\hline Mature non-pregnant & $0.8-4.1$ & $0.5-4.0$ & $1.7-10.5$ & 3.2 \\
\hline Mature-pregnant & $0.8-4.1$ & $1.6-1.9$ & $2.3-6.8$ & - \\
\hline \multicolumn{5}{|l|}{ Mean size (se, $n)$} \\
\hline Mature male & $166.5(0.5,106)$ & $217.2(1.0,63)$ & $419.8(3.2,48)$ & $275.1(4.8,19)$ \\
\hline Mature non-pregnant female & $173.3(0.7,83)$ & $223.6(1.2,67)$ & $499.1(4.8,43)$ & $283.4(11.6,2)$ \\
\hline Pregnant females & $174.8(0.6,141)$ & $223.5(1.5,8)$ & $520.7(4.9,20)$ & - \\
\hline \multicolumn{5}{|l|}{ Size-at-birth } \\
\hline Estimate size-at-birth & 90.0 & 100.0 & 200.0 & - \\
\hline Largest fetus & 90.0 & 104.0 & 199.4 & - \\
\hline Smallest free-living specimen & 90.2 & 99.8 & 230.0 & 137.0 \\
\hline Proportion of size at birth to the mean size of pregnant females & $51 \%$ & $46 \%$ & $38 \%$ & - \\
\hline Sex ratio of fetuses Female:Male $(n)$ & $1: 1.25(131)$ & $1: 0.7(10)$ & $1: 0.25(10)$ & - \\
\hline
\end{tabular}

All sizes are in centimeters, with se the standard error and $n$ the sample size.

2) Intrinsic population growth rate estimation. These age values were then used to estimate the intrinsic population growth rate $r$ for mobulids based on the updated Euler-Lotka equation (Pardo et al., 2016a,b, 2018)

$$
L_{\alpha m a t} \times b=e^{r \times \alpha m a t}-e^{-M}\left(e^{r}\right)^{\alpha m a t-1}
$$

where $L_{\alpha m a t}$ is survival to maturity as $L_{\alpha m a t}=\left(e^{-M}\right)^{\alpha m a t}$, $\mathrm{b}$ the annual reproductive output as 0.25 assuming one pup every 2 years and a 1:1 sex ratio, $\alpha$ mat the age-at-maturity and -at-pregnancy estimated in step (1), $M$ the instantaneous mortality from Pardo et al. (2016a) as $\mathrm{M}=0.087$ (95th percentile 0.079-0.097), with a maximum lifespan of 20 years for M. thurstoni and M. japanica (Pardo et al., 2016a) assuming as above a comparable lifespan, and 40 years for M. birostris (Marshall et al., 2011b), and $r$ the intrinsic population growth rate.

In the aim of documenting the degree of delay between the maturity and the first reproduction, and its consequences on population dynamic models, intrinsic population growth rate $r$ was estimated using age-at-maturity $r_{\text {mat }}\left(=r_{\text {max }}\right)$, and using age-at-pregnancy $r_{\text {preg }}$.

Finally, population doubling time $\mathrm{T}_{\mathrm{x} 2}$ was calculated as $\frac{\ln (2)}{r}$ (Simpfendorfer, 2000).

\section{RESULTS}

\section{Species Composition, Size, and Body Weight Relationships}

A total of 1,509 mobulids were examined during this study, comprising $M$. thurstoni $(n=817,54 \%)$, M. japanica $(n=450$, $30 \%), M$. birostris $(n=173,11 \%)$, and $M$. tarapacana $(n=69,5 \%)$. Manta birostris was the largest species, followed by $M$. tarapacana, M. japanica and M. thurstoni (Table 2). Both mature and immature males and females could be landed from a single net for each of the four species. Multiple species were landed in the same net as well, with instances where all four species were landed by the same vessel.

Weight-at-width data were available for $340 \mathrm{M}$. thurstoni. The heaviest female was $84 \mathrm{~kg}$ at $185 \mathrm{~cm} \mathrm{DW}$, and the heaviest male was $67 \mathrm{~kg}$ at $176 \mathrm{~cm}$ DW. Excluding the 39 pregnant females, neither sex, nor sex-width interaction were significant $(F=0.351$, $d f=-1$ and 298, $P>0.05)$. Stepwise backward elimination resulted in a single slope for both sexes (Table 4, Figures 2A,B). A significant sex-width interaction was noted when including pregnant females.

Weight-at-width data were available for $167 \mathrm{M}$. japanica. The heaviest female was $127 \mathrm{~kg}$ at $239 \mathrm{~cm} \mathrm{DW}$, and the heaviest male was $110 \mathrm{~kg}$ at $226 \mathrm{~cm}$ DW. Excluding the five pregnant females, neither sex, nor sex-width interaction was significant $(F=0.474$, 


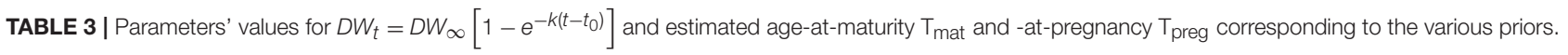

\begin{tabular}{|c|c|c|c|c|c|c|c|c|}
\hline Species & Priors & $\mathrm{DW}_{\infty}(\mathrm{cm})$ & $k\left(\right.$ year $\left.^{-1}\right)$ & $t_{0}$ (year) & $\mathrm{DW}_{\mathrm{t}-\mathrm{mat}}(\mathrm{cm})$ & $\mathbf{T}_{\text {mat }}$ (year) & $\mathrm{DW}_{\mathrm{t}-\text { preg }}(\mathrm{cm})$ & $\mathbf{T}_{\text {preg }}$ (year) \\
\hline \multirow[t]{2}{*}{ Mobula japanica } & $\begin{array}{l}\text { Pardo et al., 2016a } \\
\text { Strong prior }\end{array}$ & 299.0 & -0.12 & -1.68 & 217.0 & 9.1 & $\begin{array}{l}223.5^{\star} \\
261.1^{\star \star}\end{array}$ & $\begin{array}{r}9.8 \\
15.6\end{array}$ \\
\hline & $\begin{array}{l}\text { Cuevas-Zimbrón et al., } \\
2013\end{array}$ & 233.8 & -0.28 & -1.68 & 217.0 & 7.9 & $223.5^{\star}$ & 9.5 \\
\hline \multirow{2}{*}{ Mobula thurstoni } & $\begin{array}{l}\text { Pardo et al., } 2016 \mathrm{a} \\
\text { Weaker prior }\end{array}$ & 198.9 & -0.221 & -1.68 & 163.6 & 6.1 & $171.5^{\star \star}$ & 7.3 \\
\hline & $\begin{array}{l}\text { Cuevas-Zimbrón et al., } \\
2013\end{array}$ & 198.9 & -0.28 & -1.68 & 163.6 & 4.5 & $171.5^{\star \star}$ & 5.4 \\
\hline Manta birostris & Dulvy et al., 2014b & 707 & -0.1 & -1.68 & 448.0 & 8.6 & $532.9^{\star \star}$ & 12.6 \\
\hline
\end{tabular}

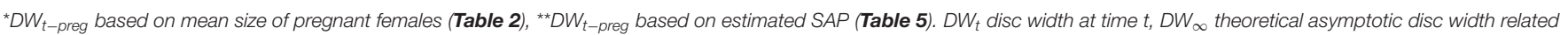
to the maximal size as $D W_{\infty}=1.01^{\star} D W_{\max }, k$ the growth coefficient, and to the theoretical age at zero length.

TABLE 4 | Relationship between body mass and disc width.

\begin{tabular}{|c|c|c|c|c|c|c|}
\hline Species & Age class & Fig & $n$ & $a(\mathrm{se})$ & $b(\mathrm{se})$ & $r^{2}$ \\
\hline \multirow[t]{2}{*}{ Mobula thurstoni } & All & 2.a & 301 & $5.414 \mathrm{e}-06(2.405-06)$ & 3.139 (8.698e-02) & 0.97 \\
\hline & Fetus only & 2.b & 91 & 5.220e-05 (1.789e-05) & 2.657 (7.999e-02) & 0.96 \\
\hline Mobula japanica & All & 2.c & 162 & 6.506e-05 (3.047e-05) & $2.641(8.718 \mathrm{e}-02)$ & 0.93 \\
\hline Manta birostris & Fetus only & 2.d & 5 & $1.874 \mathrm{e}-05$ (3.105e-05) & $2.884(3.398 \mathrm{e}-01)$ & 0.99 \\
\hline Mobula tarapacana & All & $2 . e$ & 8 & 7.344e-07 (1.010e-06) & $3.486(2.460 \mathrm{e}-01)$ & 0.98 \\
\hline
\end{tabular}

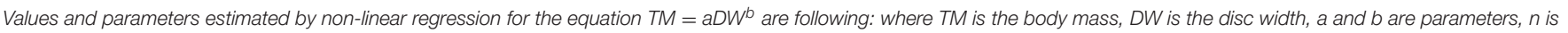
the number of specimens, $r^{2}$ is the square of correlation coefficient.

$d f=-1$ and 159, $P>0.05)$. Stepwise backward elimination resulted in a single slope for both sexes (Table 4, Figure 2C).

Weight-at-width data were only available for $8 \mathrm{M}$. tarapacana. The lightest on was $48 \mathrm{~kg}$ at $164 \mathrm{~cm} \mathrm{DW}$, and the heaviest was $299 \mathrm{~kg}$ at $295 \mathrm{~cm} \mathrm{DW}$ (Table 4, Figure 2D). Weight-at-width data for $M$. birostris were only available for five fetuses. The lightest one was $2.6 \mathrm{~kg}$ at $54.8 \mathrm{~cm} \mathrm{DW}$, and the heaviest was $29 \mathrm{~kg}$ at $138 \mathrm{~cm} \mathrm{DW}$ (Table 4, Figure 2E).

\section{Maturity and Pregnancy Ogives}

For all species, maturity ogives were estimated for both sexes separately and maturity was reached at a larger size in females than in males (Figure 3). Depending on the species, females and males matured at $64-87$ and 54-82\%, respectively, of the maximum size in the literature, and $81-87$ and $69-82 \%$, respectively, of the maximal size recorded in this study (Table 2).

Pregnancy ogives were estimated for all species except $M$. tarapacana, and shifted to the right of maturity ogives (Figure 3). For M. thurstoni, only $9 \%(n=6)$ of mature females were pregnant when reaching the size-at-maturity (Table 5), and only $15 \%(n=33)$ were pregnant between size-at-maturity and -at-pregnancy. Only two mature female $M$. tarapacana were included in the analysis, resulting in a large standard error (se $=6108.9$ ). The maturity ogive for this species should therefore be taken with caution, and the mean size of mature specimens
$(283.4 \mathrm{~cm}$, se $=11.6)$ could be used until accurate maturity ogives can be provide.

\section{Fecundity and Size-at-Birth}

In total, data were collected from 201 fetuses comprising 164 M. thurstoni, 12 M. japanica, and 25 M. birostris. No fetus was observed for $M$. tarapacana. Pregnant females carried a single fetus in the left uterus for all species (98.6\%). Exceptions were observed two times ( $1.4 \%$ of pregnancy) when pregnant M. thurstoni carried twins in the left uterus. These fetuses had similar size than other single embryos at the same development stage, based on morphological appearance and coloration. Sizeat-birth represents $38-51 \%$ of the maternal size, depending on the species (Table 2). Smaller species carried proportionally larger embryos. For all species, the sex ratios did not differ significantly from parity $\left(\chi^{2}, d f=1, P>0.05\right.$; Table 2$)$.

\section{Ovarian Follicles}

The largest follicle diameter (LFD) was measured from 162 M. thurstoni, 103 M. japanica, 47 M. birostris, and 3 $M$. tarapacana, including mature and immature specimens. For all species, only the left ovary was active, showing various stages of follicle development with increasing maturity from the posterior to the anterior of the ovary, whereas the right 


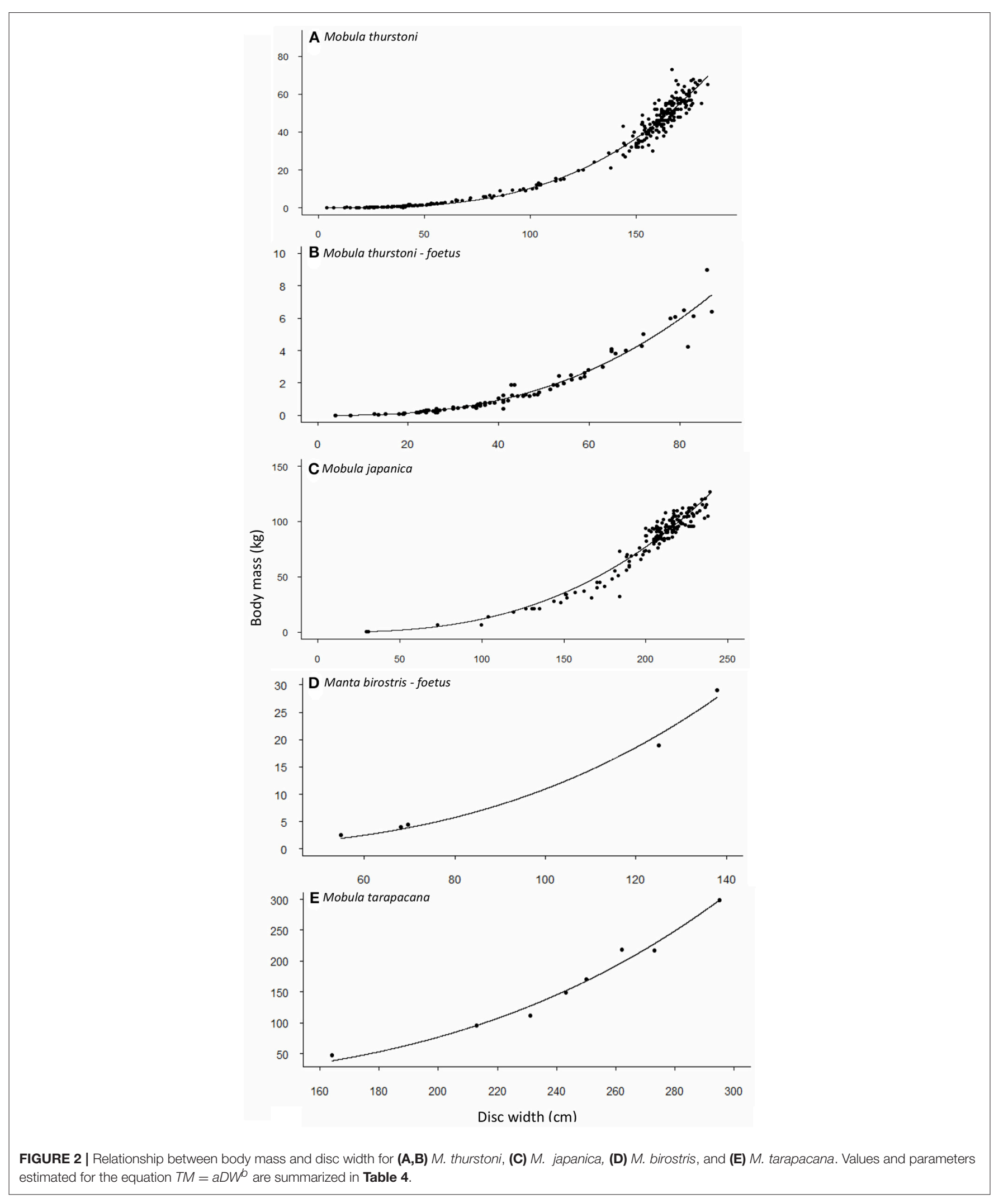



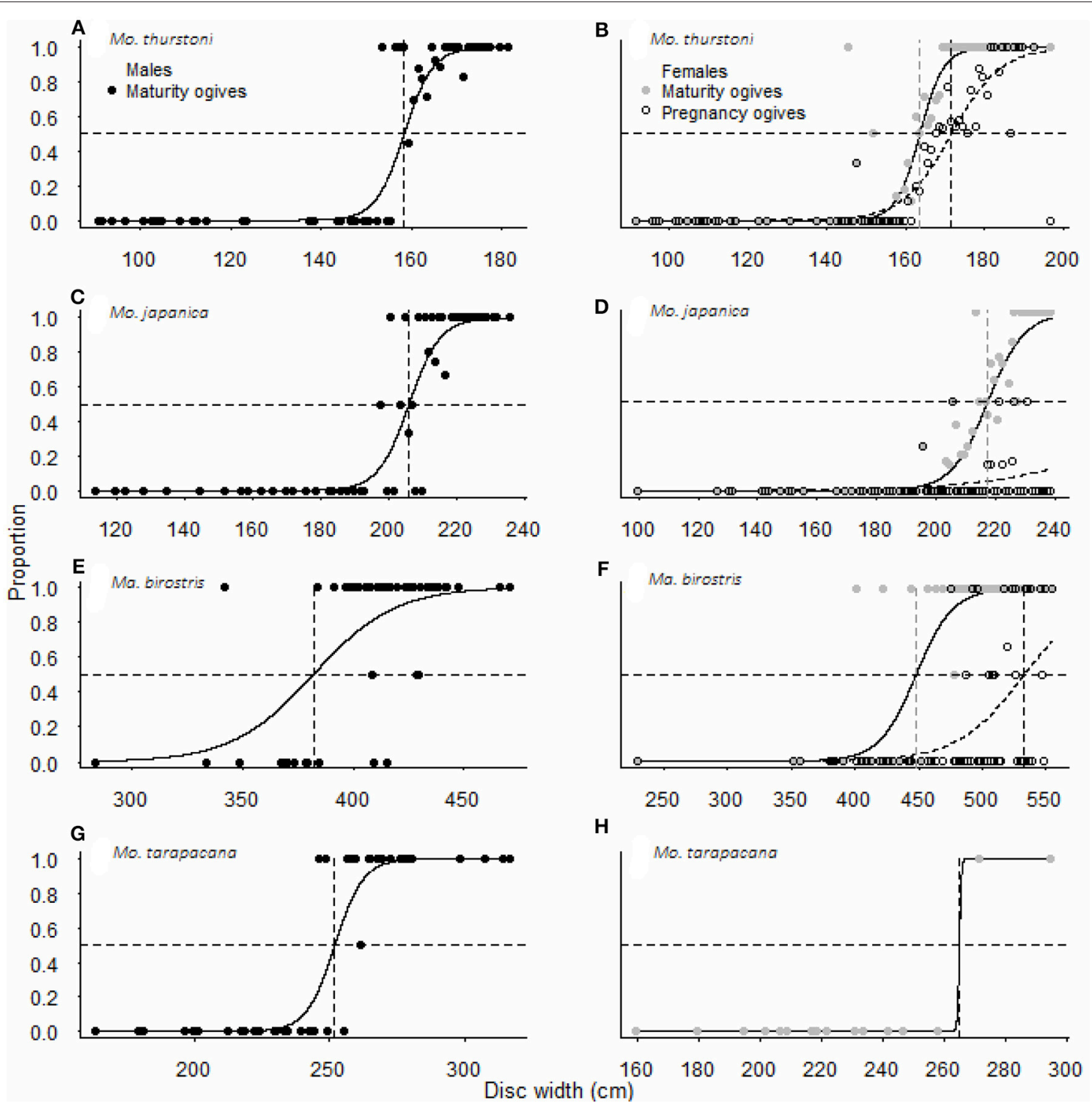

FIGURE 3 | Maturity and pregnancy ogives for (A,B) Mobula thurstoni, (C,D) Mobula japanica, (E,F) Manta birostris, and (G,H) Mobula tarapacana. Dashed lines are

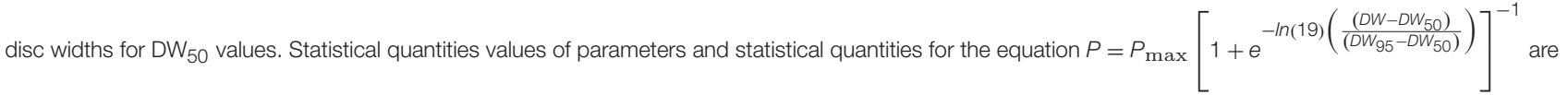
summarized in Table 5. DW the total size, $P$ the proportion of specimens at $D W, D W 50$ the size at which $50 \%$ of the population is mature or pregnant, $D W W_{95}$ the size at which $95 \%$ of the population is mature or pregnant.

one remained quiescent. The LFD in the left ovary ranged $4.0-$ $10.5 \mathrm{~cm}$ depending on the species (Table 2), while follicles in the right ovary did not develop, with a LFD of $0.0-0.7 \mathrm{~cm}$. Henceforth the LFD refers to the largest follicle from the left ovary. For M. birostris, the exceptional presence of a developing follicle of $1.8 \mathrm{~cm}$ diameter in the right ovary was observed in one pregnant female, although it is still small (20\% of maximum LFD) compared to mature follicles from left ovaries observed in this study. Furthermore, this specimen presented a follicle of $3.4 \mathrm{~cm}$ diameter in the left ovary and the fetus was in the left uterus. For M. tarapacana, $82 \%(n=17)$ of the females had epigonal organs liquefied, even though they were landed at the same time as the other species, which had intact epigonal organs.

\section{Reproductive Cycle}

Investigation of the ovarian cycle was based on the LFD of mature females only, from $114 M$. thurstoni, $45 \mathrm{M}$. japanica, and $38 \mathrm{M}$. birostris. We did not find a significant difference for the LFD throughout the months for M. thurstoni (Kruskall-Wallis, $d f=7$, $P>0.05$, Figure 4A), $M$. japanica (Kruskall-Wallis, $d f=3, P$ $>0.05$, Figure 4B), and M. birostris (Kruskall-Wallis, $d f=6, P$ $>0.05$, Figure 4C). It was not possible to determine so for $M$. 
TABLE 5 | Maturity and pregnancy ogives parameters for Mobula thurstoni, Mobula japanica, Manta birostris, and Mobula tarapacana.

\begin{tabular}{|c|c|c|c|c|c|c|c|c|c|}
\hline Species & Sex & Analysis & Fig & $\mathbf{N}$ & $n$ & $\mathrm{DW}_{50}( \pm \mathrm{se})$ & $\mathrm{DW}_{95}( \pm \mathrm{se})$ & Intercept & $x^{2}$ \\
\hline \multirow[t]{3}{*}{ Mobula thurstoni } & Male & SAM & $3 . a$ & 160 & 106 & $158.4(0.9)$ & $167.7(1.5)$ & -48.99 & 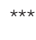 \\
\hline & Female & SAM & $3 . b$ & 353 & 224 & $163.6(0.6)$ & $172.8(1.1)$ & -91.67 & 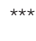 \\
\hline & & SAP & 3.b & 353 & 141 & $171.5(0.8)$ & $189.9(2.4)$ & -167.06 & 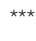 \\
\hline \multirow[t]{3}{*}{ Mobula japanica } & Male & SAM & 3.c & 108 & 63 & 205.8 (1.6) & 219.2 ( 2.7$)$ & -30.74 & *** \\
\hline & Female & SAM & 3.d & 206 & 77 & $217.8(1.1)$ & $234.0(2.8)$ & -39.50 & *** \\
\hline & & SAP & 3.d & 206 & 8 & $261.1(17.9)$ & $301.5(35.7)$ & -19.06 & ** \\
\hline \multirow[t]{3}{*}{ Manta birostris } & Male & SAM & $3 . e$ & 63 & 48 & $381.9(8.7)$ & $436.2(12.4)$ & -24.42 & 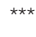 \\
\hline & Female & SAM & $3 . f$ & 85 & 63 & 448.0 (6.9) & 490.5 (10.4) & -16.26 & 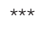 \\
\hline & & SAP & $3 . f$ & 85 & 20 & $532.9(9.6)$ & $610.3(30.1)$ & -35.72 & 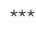 \\
\hline \multirow[t]{2}{*}{ Mobula tarapacana } & Male & SAM & 3.9 & 42 & 19 & $252.1(3.4)$ & $267.5(6.2)$ & -7.88 & 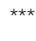 \\
\hline & Female & SAM & 3.h & 17 & 2 & 264.8 (6108.9) & 265.8 (6298.4) & $-1.05 e-09$ & *** \\
\hline
\end{tabular}

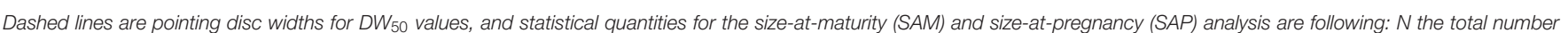

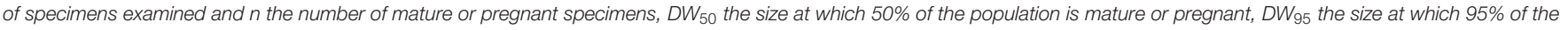
population is mature or pregnant, Intercept the intercept value for the model, and $\chi^{2}$ the probability of statistical significance with ${ }^{* * *} P<0.001$, ${ }^{\star *} P<0.01$.

tarapacana, with only one record of a $3.2 \mathrm{~cm}$ LFD from a $271.8 \mathrm{~cm}$ DW mature female.

The timing and periodicity of pregnancy was based on fetuses collected from $164 M$. thurstoni, and $25 M$. birostris. Due to the low number of fetuses for M. japanica $(n=11)$, this species was not included in the analysis. For M. thurstoni (Figure 5A), the mean fetus size (cm DW) differed between the months of December (49.8; se $=2.6 ; n=38$ ) and May (38.5; se $=2.4$; $n=63$ ) (Pairwise Wilcoxon, $P<0.05$ ). However, near-term fetuses were observed throughout the season. For M. birostris, the mean fetus size did not differ by month (Pairwise Wilcoxon, $P>0.05$; Figure 5B) and near-term fetuses were recorded in February, March and April.

From November 2015 to June 2016, specimens were sexed for 1,257 M. thurstoni (71\% of $M$. thurstoni landed), as well as $110 \mathrm{M}$. birostris (99\%), and $777 \mathrm{M}$. japanica (89\%). From these subsets, pregnant females represented $20 \%(n=129), 9 \%(n=10)$, and $1 \%(n=10)$ for M. thurstoni, M. birostris and $M$. japanica, respectively. During November and December 2015, 12 (67\%) M. japanica mature females landed presented the same reproductive stage with a large and thick left uterus, and well developed red-purple trophonemata, suggesting a probable recent parturition.

\section{Von Bertalanffy and Population Growth Rate}

Depending on species and priors, age-at-maturity estimations are 4.5-9.1 years, and 5.4-12.6 years for the age-at-pregnancy estimations (Table 6). The mean delay between maturity and pregnancy represents about a year and half (1.6, se $=0.5$ ), with a minimum of 0.7 year for $M$. japanica, up to 4 years for $M$. birostris. These age estimations result in $\mathrm{r}_{\operatorname{mat}}\left(=\mathrm{r}_{\max }\right)$ between 0.016 and 0.055 year $^{-1}$ and $r_{\text {preg }}$ between 0.008 and 0.044 year $^{-1}$.

Considering age-at-maturity, population doubling time represents 12.6-43.3 years, and 15.8-86.6 years with age-at-pregnancy.

\section{DISCUSSION}

\section{Life History Traits}

In the present study, we provide female maturity ogives for four mobulid species, where females mature at a larger size than males, findings that are essential in population dynamics to assess the sustainability of this fishery and any other comparable fisheries. Male maturity ogives were consistent with literature values for $M$. japanica and M. tarapacana in other regions (NotarbartoloDi-Sciara, 1987, 1988; White et al., 2006b; Couturier et al., 2012; Pardo et al., 2016a,b), while males reached maturity at larger sizes than previously reported for M. birostris (Marshall et al., 2011b) and M. thurstoni (Notarbartolo-Di-Sciara, 1988; White et al., 2006b; Walls et al., 2016). Despite a lack of mature M. tarapacana, the smallest mature female $(271.8 \mathrm{~cm}$ DW) was within the size range at maturity $(270.0-280.0 \mathrm{~cm} \mathrm{DW})$ in the Gulf of California (Notarbartolo-Di-Sciara, 1988). We found sexual dimorphism in the size-at-maturity for all species, a trait commonly observed for sharks and rays likely related to the energetic and physical needs for the females to support offspring (Cortés, 2000).

Results from disc width-weight relationships for M. thurstoni and $M$. japanica show that males and females exhibit similar growth rates, supporting that females reach maturity at older age than males, rather than females growing faster than males to reach a larger size, indicating a delayed onset of sexual maturity in females. Females reached maturity at $\sim 80 \%$ of their maximal size, which is among the latest for elasmobranchs (Cortés, 2000), and underlines the extremely conservative life history of mobulids (Dulvy et al., 2014b).

Results show a delayed onset between maturity and pregnancy, meaning that at least $50 \%$ of females within the population do not reproduce when reaching maturity. Such a delay is common among live-bearing elasmobranchs, because of the important maternal inputs due to a relatively large fetus nourished over a long period, and selection pressure for large body size in females is expected (Cortés, 2000; Goodwin et al., 2002; Sims, 2003). A near-term M. thurstoni fetus represents up to half the disc width and $1 / 7$ th of the weight of 

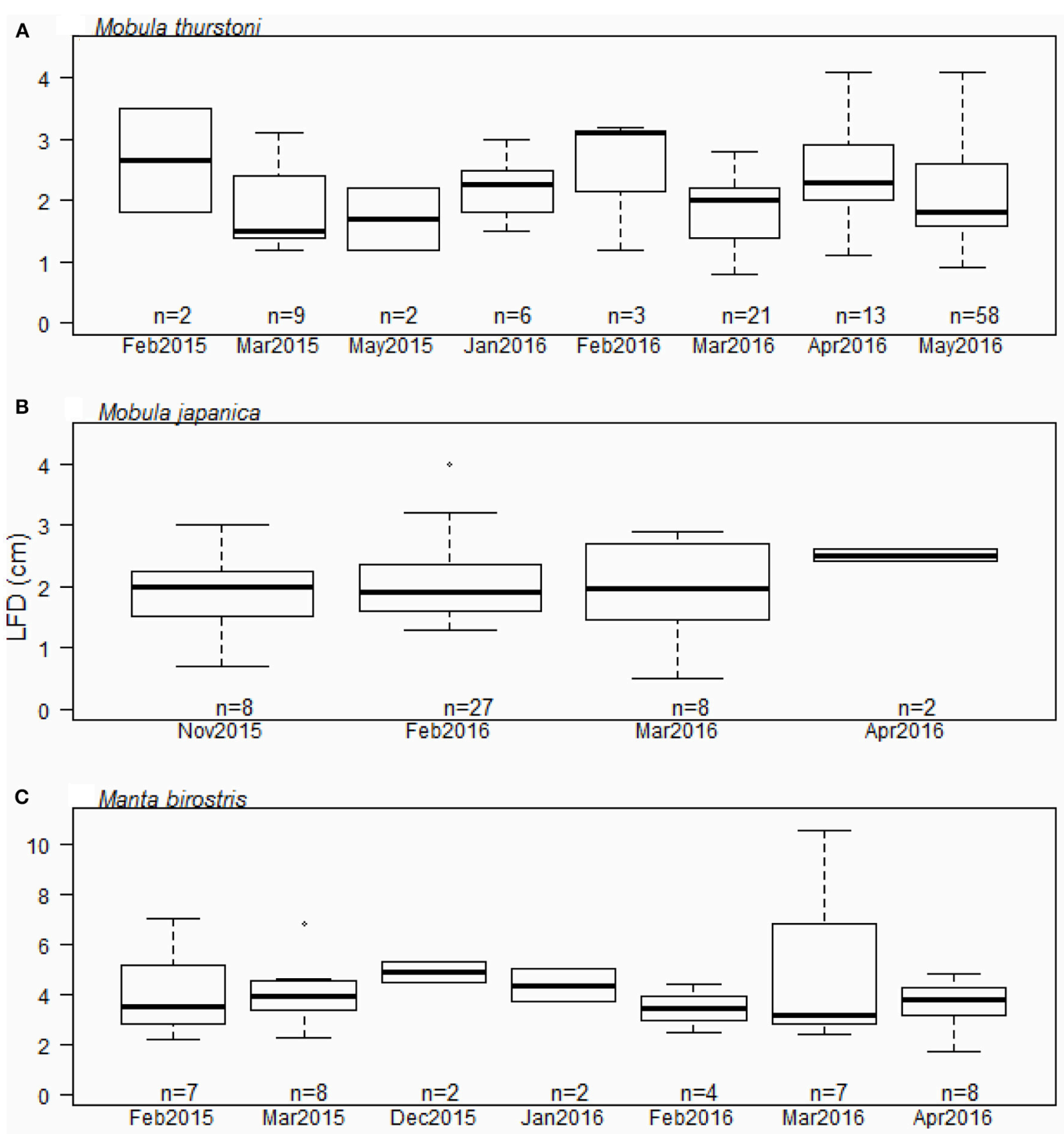

FIGURE 4 | Largest follicle diameter distribution per month for (A) M. thurstoni, (B) M. japanica, and (C) M. birostris. For each distribution, horizontal lines from bottom to top: lower value, first quartile, median, third quartile, and upper value. Dots in $\mathbf{( B , C )}$ represent suspected outliers.

the mother. This difference in sizes might also reflect the long gestation period (Musick and Bonfil, 2004) for these species currently assumed to last approximately a year (NotarbartoloDi-Sciara, 1988; Marshall and Bennett, 2010; Dulvy et al., 2014b). Similar estimates of delay have been reported in other chondrichthyes, such as the piked spurdog Squalus megalops (Braccini et al., 2006), the spot-tail shark Carcharhinus sorrah, or the Australian blacktip shark Carcharhinus tilstoni (Harry et al., 2013).

The present age-at-maturity estimations $(\sim 5-9$ years, depending on the species and the priors) are consistent within the literature for mobulids (Dulvy et al., 2014b; Pardo et al., 2016a; Nozu et al., 2017), supporting the plausibility of these scenarios. For M. japanica, an additional 2-3 years compared to the previous estimation of age-at-maturity of 5-6 years (Pardo et al., 2016a) reflect an entire reproductive cycle, based on a 2 -year interbreeding interval. It therefore represents one less pup per female within the population over their complete lifespan. This finding affects the maximum population growth rate $r_{\max }$ $\left(=r_{\text {mat }}\right)$ and results in lower values than previously estimated for M. japanica $\left(0.077\right.$ year $^{-1}, 95$ th percentile $=0.042-0.108$, Pardo et al., 2016a). 


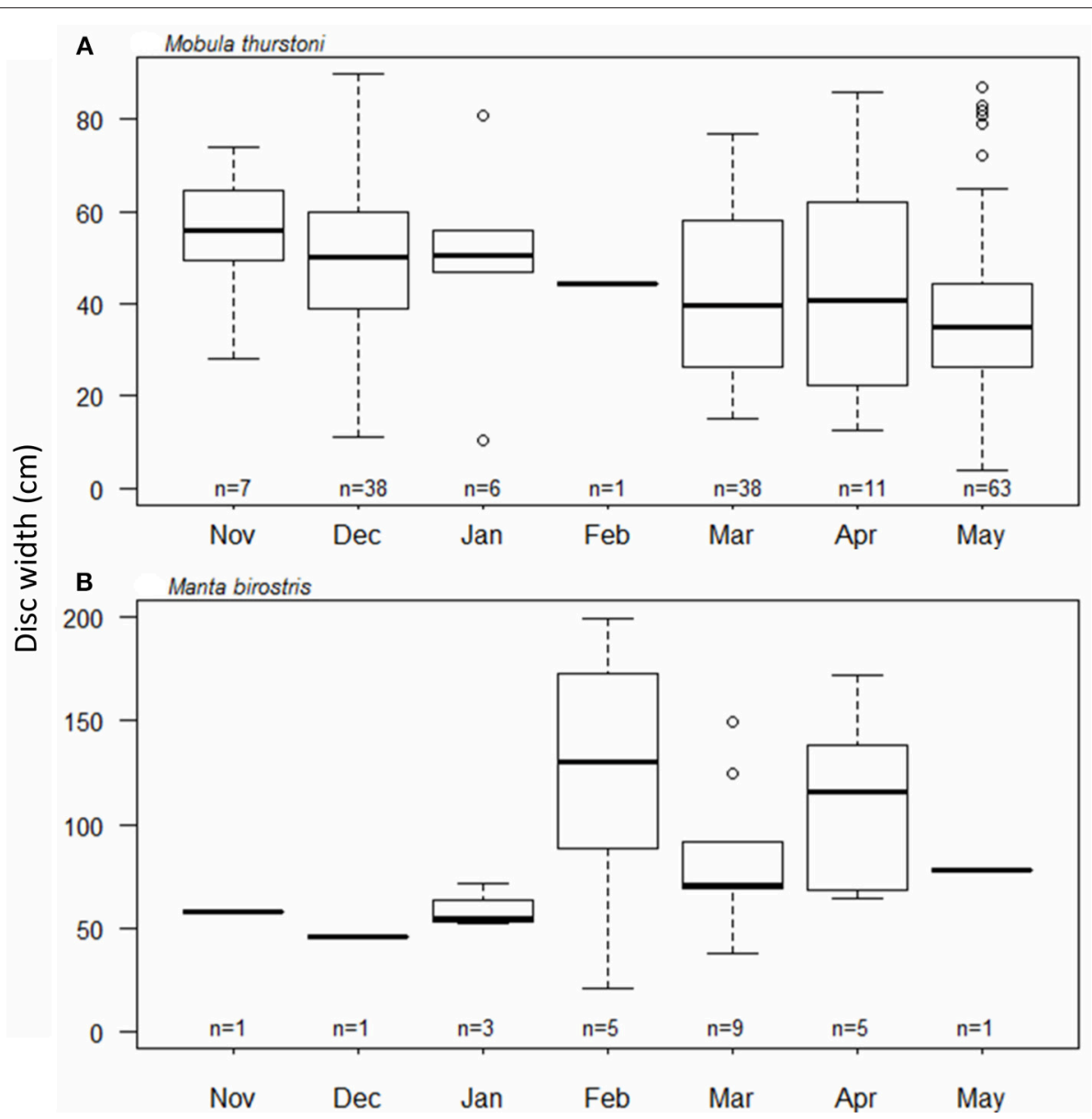

FIGURE 5 | Fetus size distribution throughout the months for (A) M. thurstoni, and (B) M. birostris. For each distribution, horizontal lines from bottom to top: lower value, first quartile, median, third quartile, and upper value. Circles represent suspected outliers.

Mobula thurstoni has a higher population growth rate than $M$. japanica although we assumed a similar growth curve, which suggests that $M$. thurstoni reproduce faster, being a slightly smaller species with a possible higher vulnerability to predation.

Realistic scenarios for $M$. japanica's $\mathrm{r}_{\text {preg }}$ are based on the mean size of pregnant females, while estimations based on sizeat-pregnancy resulted in implausible values described by Pardo et al. (2018). Similarly, realistic scenarios for M. thurstoni in the present study are based on the weaker prior from Pardo et al. (2016a), and prior from Cuevas-Zimbrón et al. (2013), and estimation based on the strong prior were excluded due to implausible values. It shows that population dynamics based solely on maturity ogives would overestimate the recruitment outputs and reproductive potential for species exhibiting a similar delay between maturity and pregnancy. Authors are thus encouraged to document the degree of delay between maturity and pregnancy in order to re-estimate and compare those new values.

Present results show that $M$. birostris are born at $\sim 200-210 \mathrm{~cm}$ DW, which is larger than the free-living size range of $130-170 \mathrm{~cm}$ DW reported for Manta spp. in southern Mozambique (Marshall et al., 2008). However, the subsequent revision of the genus Manta (Marshall et al., 2009), and photographic evidence shows that this size-at-birth estimation was for M. alfredi (Marshall et al., 2008), which is the smaller of the two species. Consequently, the size-at-birth values reported in this study for $M$. birostris should be used in demographic models. Present estimations of size-at-birth for $M$. thurstoni and $M$. japanica are slightly larger than literature values from elsewhere (Notarbartolo-Di-Sciara, 1988; White et al., 2006b), and size of the smallest free-swimming $M$. tarapacana in this study $(137 \mathrm{~cm} \mathrm{DW})$ supports the range suggested in Sri Lanka (117-132 cm DW, Pardo et al., 2016c) although further validation will be appropriate due to the small samples size.

The absence during the study of specific periods for ovulation and the wide embryo size-ranges throughout the months do not show any clear seasonality in the reproductive cycle at the population level for both $M$. thurstoni and M. birostris. The study period only covered seven months of the year, and so their activities (i.e., reproduction, movements) during the rest of the year when they were not landed in Jagna is unknown. Despite this lack of seasonality on the ovarian and reproductive cycles, 
TABLE 6 | Intrinsic population growth rate and population doubling time relating to the age-at-maturity and -at-pregnancy for M. japanica, M. thurstoni, and M. birostris.

\begin{tabular}{|c|c|c|c|c|c|c|c|}
\hline Species & Priors & $\mathbf{T}_{\text {mat }}$ & $\begin{array}{l}\mathbf{r}_{\text {mat }}(95 \text { th } \\
\text { percentile) }\end{array}$ & $\mathbf{T}_{\mathrm{x} 2-\mathrm{mat}}$ & $\mathbf{T}_{\text {preg }}$ & $\begin{array}{l}\mathbf{r}_{\text {preg }} \text { (95th } \\
\text { percentile) }\end{array}$ & $\mathbf{T}_{\mathrm{x} 2-\text { preg }}$ \\
\hline \multirow[t]{2}{*}{ Mobula japanica } & $\begin{array}{l}\text { Pardo et al., 2016a } \\
\text { Strong prior }\end{array}$ & 9.1 & $\begin{array}{c}0.016 \\
(0.006-0.024)\end{array}$ & 43.3 & $\begin{array}{c}9.8^{\star} \\
15.6^{\star \star}\end{array}$ & $\begin{array}{c}0.012 \\
(0.002-0.020) \\
0^{\star \star \star}(0-0)\end{array}$ & $\begin{array}{c}57.8 \\
-\end{array}$ \\
\hline & $\begin{array}{l}\text { Pardo et al., 2016a } \\
\text { Weaker prior }\end{array}$ & 7.4 & $\begin{array}{c}0.027 \\
(0.017-0.035)\end{array}$ & 25.7 & $8.3^{*}$ & $\begin{array}{c}0.021 \\
(0.011-0.029)\end{array}$ & 33.0 \\
\hline \multirow[t]{3}{*}{ Mobula thurstoni } & $\begin{array}{l}\text { Pardo et al., 2016a } \\
\text { Strong prior }\end{array}$ & 12.7 & $0^{\star \star \star}(0-0.008)$ & - & $14.9^{\star \star}$ & $0^{\star \star \star}(0-0.001)$ & - \\
\hline & $\begin{array}{l}\text { Pardo et al., } 2016 a \\
\text { Weaker prior }\end{array}$ & 6.1 & $\begin{array}{c}0.037 \\
(0.027-0.045)\end{array}$ & 18.7 & $7.3^{\star \star}$ & $\begin{array}{c}0.028 \\
(0.018-0.036)\end{array}$ & 24.8 \\
\hline & $\begin{array}{l}\text { Cuevas-Zimbrón et al., } \\
2013\end{array}$ & 4.5 & $\begin{array}{c}0.055 \\
(0.045-0.063)\end{array}$ & 12.6 & $5.4^{\star \star}$ & $\begin{array}{c}0.044 \\
(0.034-0.052)\end{array}$ & 15.8 \\
\hline
\end{tabular}

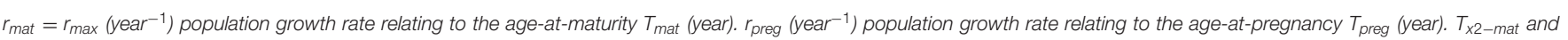

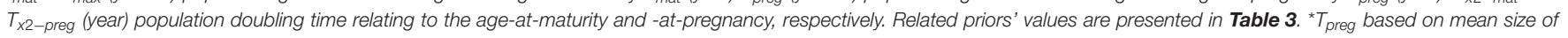
pregnant females (Table 2), ${ }^{\star \star} T$ preg based on estimated size-at-pregnancy (SAP, Table 5), ${ }^{\star \star \star}$ implausible values.

for $M$. thurstoni higher proportions of pregnant females were observed during particular months in 1 year (up to 38\% in May 2016, $n=63$ ). Females at different stages of pregnancy could be caught in the same net refuting a geographical segregation between near-term pregnancy and the rest of the population. Coordinated breeding activity was suggested in Baja California (Notarbartolo-Di-Sciara, 1988), as well as off northern New South Wales for M. kuhlii cf. eregoodootenkee (Broadhurst et al., 2018), although data were sparse in both cases. In Mozambique, M. alfredi seemed to show seasonal peaks (Marshall and Bennett, 2010), while in Hawaii mating trains were observed during 10 months of the year peaking in January and April (Deakos et al., 2011). The combined evidence supports the ability of mobulids to reproduce year round, with some cases specifying a period of higher reproductive activity.

Considering the high amount of energy invested in reproduction (i.e., pregnancy, potential migration to mating site), food availability is suggested to be an important driver for reproductive success. Planktivorous elasmobranchs tend to follow productive ephemeral pulses that may vary in time and space (Sims, 2003; Rohner et al., 2013). The presence of higher numbers of pregnant females in the region could be related to the high primary productivity and food availability in the area for these species (Rohner et al., 2017; Stewart et al., 2017). Investigations based on catch data coupled with GPS tracks of fishing vessels and environmental parameters (i.e., primary productivity) would provide further insight on areas with higher densities of pregnant females and this relationship with food availability.

A proportion of observed mature females ( $\left.\mathrm{DW}_{50 \text { pregnancy }}\right)$ for $M$. thurstoni, $M$. japanica and $M$. birostris were neither pregnant nor had recently given birth, supporting a resting period between pregnancies. This suggests that a proportion of females within the population do not reproduce every year and corroborates observations reported in the literature of a potential biennial or triennial reproductive cycle (Notarbartolo-Di-Sciara, 1988; Marshall and Bennett, 2010; Dulvy et al., 2014b; Broadhurst et al., 2018). The length of an inter-pregnancy period could depend on the availability of resources, suggested previously as a driver for reproductive potential. The low proportions of pregnant females within those populations (M. thurstoni $20 \%$, M. birostris $9 \%$, and M. japanica 1\%) underline the vulnerability of this cohort. It is an actual baseline regarding reproductive success in demographic models.

\section{Reproductive Biology}

This study reports the presence of twins in $M$. thurstoni. Despite the usual production of a single offspring per litter for all mobulids, a rare observation of twins was also reported from Mozambique in M. alfredi (Marshall and Bennett, 2010). Here, two sets of twins were observed in $M$. thurstoni, representing $1.4 \%$ of the pregnancies recorded in this study. Both sets were from the left uterus and were within the normal size range of embryos, and not smaller as could be expected, as reported in cownose rays Rhinoptera bonasus were twins were below the mean size of single embryos (Fisher, 2010). A significant negative correlation between mean litter size and offspring size was also stated for the Dasyatidae family (Pierce et al., 2009), and more generally as a life history correlation in elasmobranchs (Cortés, 2000). However, this assumption was not met in the two sets of twins here. Observations of more twins and investigation of their anatomical development would give better opportunities to test this possible correlation for $M$. thurstoni.

Ovarian follicles developed only on the left ovary, supporting previous observations for these species (Notarbartolo-Di-Sciara, 1988; Broadhurst et al., 2018), as well as for many other batoids, such as the cownose rays (Fisher, 2010) and other stingrays (Pierce et al., 2009; Mejía-Falla et al., 2014). One exceptional 
observation of a female $M$. birostris with a surprisingly developed follicle in the right ovary suggest that production of a pup in the right uterus could be possible in rare cases. Despite the nonmaturation of the follicles in the right ovary, both right and left uteri appear functional, with a similar developmental stage of the wall and the trophonemata, and the regular presence of a green or white substance in both uteri. Further support comes from a female cownose ray $R$. bonasus observed with a fetus in the right uterus (Fisher, 2010); the species usually exhibits only the maturation of the left ovary. Nonetheless, only the left uterus was observed to further develop to allow embryonic development. Although both specimens from the two present sets of twins were from the left uterus, given the relative size-at-birth and the potential energy investment for the mother, the development of only one ovary would avoid the risk of carrying two offspring at the same time and could thus be a beneficial evolutionary trait.

\section{Mobulids in the Bohol Sea}

This study confirms the presence of four mobulids within an important fishing ground. While the targeted fishery in Bohol has been banned since April 2017, further monitoring of bycatch from tuna fisheries and targeted landings at other sites in the Bohol Sea is needed. As the different mobulids were regularly caught in the same net, it is certain that these species all share the same habitat, at least for a portion of the time. This niche overlap is supported by previous work on stomach content analyses in the short term (Rohner et al., 2017) and stable isotope analyses in the longer term (Stewart et al., 2017). A further 5th species, the reef manta ray Manta alfredi, was recently confirmed from the area, but only found once over four monitoring seasons (Rambahiniarison et al., 2016). Manta alfredi were also caught in a nearby fishery $\sim 130 \mathrm{~km}$ from Jagna, off Dinagat Island in the Surigao Strait (Acebes et al., 2016). It is unclear why $M$. alfredi were not caught together with the other mobulids, but this trend may indicate habitat partitioning (Marshall et al., 2009; Deakos et al., 2011; Rambahiniarison et al., 2016), or local extirpation. Historical fishing grounds were closer to the coast than at present (Acebes and Tull, 2016), covering a habitat with different oceanographic characteristics (i.e., 0$500 \mathrm{~m}$ depth, slower currents in historical fishing grounds). Although $M$. alfredi is not as coastal as assumed in the past (Jaine et al., 2014), previous local population extinction could explain its current absence among the landed species. With at least five species confirmed, the Bohol Sea is an important habitat for mobulids, representing a pupping and a mating ground for at least three species $M$. thurstoni, M. japonica, and $M$. birostris, based on the fetus size distribution throughout the season.

The size ranges of the mobulids caught in the Bohol Sea were largely within the literature values from elsewhere, although we extend here the maximum size of $M$. thurstoni from $180 \mathrm{~cm}$ (White et al., 2006b; Couturier et al., 2012) to $197 \mathrm{~cm} \mathrm{DW,} \mathrm{with}$ regular records of large females over $190 \mathrm{~cm}$ DW. Moreover, we record a larger size range for $M$. birostris in the Philippines than in Indonesia (White et al., 2006b). Forty-six percent $(n=39)$ of females were larger than $500 \mathrm{~cm}$ DW in the Bohol Sea, while this class was not reported in the catch from Indonesia (White et al., 2006b), and $73 \%(n=48)$ of the males were larger than the maximum size reported in Indonesia (200-400 cm DW; White et al., 2006b). Comparisons are however delicate because results from Indonesia were obtained before the re-description of the genus Manta, resulting in possible species misidentification.

Many mobulids are distributed globally, hence the same species are reported from around the world (Croll et al., 2015). However, variations in species and population composition reported could reflect preferential distribution areas. The small number of mature female $M$. tarapacana $(12 \%, n=2)$ and the absence of pregnant individuals for this species in the Bohol Sea is in contrast with observations from Azores, where females visually appearing to be pregnant are seen weekly at least between June and October (Ana Sobral, pers. comm.). This could suggest that $M$. tarapacana segregate based on their maturity status. Further investigations are needed to better understand the ecology and distribution of this species locally and worldwide.

Recent studies on the movements and population connectivity of $M$. birostris did not show any long-range migratory movements (Graham et al., 2012; Stewart et al., 2016), but a fine-scale population structure with non-overlapping geographic ranges (Stewart et al., 2016). These findings suggest higher isolation than previously assumed between sub-populations in these different regions, and the possibility of local populations with little exchange among them. If a $M$. birostris population exhibits similar isolation within the Bohol Sea, its harvest would highly increase the risk of local extinction, and consequently local fishing management strategies could have a clear impact on their population recovery. Further studies are needed to better understand the movements of these species, both geographically and temporally, while continuous monitoring on landings and area-specific conservation actions in the Bohol Sea are needed to anticipate and reduce by-catch by regulating and limiting non-selective fishing gears such as gill nets.

Although mobulids can exhibit diverse ecological behavior (e.g. schooling, deep-diving, distribution range), reproductive traits are consistent among species such as a similar age-atmaturity (i.e., 7-10 years old for M. alfredi Dulvy et al., 2014b; Nozu et al., 2017, M. japanica, M. thurstoni, and M. birostris) and their low number of pups in a lifespan. Population growth rate for these species are extremely low, lower than the whale shark Rhincodon typus (Pardo et al., 2016a) recently reclassified as "endangered" on the IUCN redlist (Pierce and Norman, 2016), and similar to the "critically endangered" western small tooth sawfish Pristis pectinata (Simpfendorfer, 2000; Carlson et al., 2013). Doubling population times show that it would take decades, and more than a generation for these populations to recover after stock depletion. In light of the natural susceptibility to the detrimental effects of over-exploitation of mobulids, based on their intrinsic biological characteristics presented here, and in-line with the new amended Philippines Fisheries Code (R.A 10654) and the procedure delineated in the "CITES Non-detriment Findings Guidance for Shark Species" (MundyTaylor et al., 2014) at the current status of the population, the sustainability of any level of harvesting and fishery exploitation seems unrealistic and strongly discouraged. 


\section{ETHICS STATEMENT}

Data were collected under the approval of the Local Government Unit (LGU) of Jagna, Bohol, the Department of AgricultureBureau of Fisheries and Aquatic Resources Region 7 and the Bohol Environmental Management Office, and with the support of the local community. Prior Informed Consent for research was renewed yearly by the LGU of Jagna.

\section{DATA AVAILABILITY STATEMENT}

The data analyzed for this study can be found in the Dryad https://doi.org/10.5061/dryad.f3bm7 (Rambahiniarison et al., 2018).

\section{AUTHOR CONTRIBUTIONS}

JR designed the study, collected field data, carried out the analyses and drafted the manuscript. ML collected field data. CR, RM, and JL collected field data and helped draft the manuscript. SS helped draft the manuscript. GA helped draft the manuscript and coordinated field work. AP collected field data, helped draft the manuscript and coordinated field work. All authors gave final approval for publication.

\section{REFERENCES}

Acebes, J. M. V., Barr, Y., Pereda, J. M. R., and Santos, M. D. (2016). Characteristics of a previously undescribed fishery and habitat for Manta alfredi in the Philippines. Mar. Biodiver. Rec. 9:97. doi: 10.1186/s41200-0160098-2

Acebes, J. M. V., and Tull, M. (2016). The history and characteristics of the mobulid ray fishery in the Bohol Sea, Philippines. PLoS ONE 11:e0161444. doi: 10.1371/journal.pone.0161444

Braccini, J. M., Gillanders, B. M., and Walker, T. I. (2006). Determining reproductive parameters for population assessments of chondrichthyan species with asynchronous ovulation and parturition: piked spurdog (Squalus megalops) as a case study. Mar. Freshwater Res. 57, 105-119. doi: 10.1071/MF05076

Broadhurst, M. K., Laglbauer, B. J. L., Burgess, K. B., and Coleman, M. A. (2018). Reproductive biology and range extension for Mobula kuhlii cf. eregoodootenkee. Endangered Species Res. 35, 71-80. doi: 10.3354/esr00876

Bustamante, C., Barría, C., Vargas-Caro, C., Ovenden, J. R., and Bennett, M. B. (2015). The phylogenetic position of the giant devil ray Mobula mobular (Bonnaterre, 1788) (Myliobatiformes, Myliobatidae) inferred from the mitochondrial genome. Mitochondrial. DNA A DNA Mapp. Seq. Anal. 27, 3540-3541.doi: 10.3109/19401736.2015.1074208

Cabrera, O. C., Villanoy, C. L., David, L. T., and Gordon, A. L. (2011). Barrier layer control of entrainment and upwelling in the Bohol Sea, Philippines. Oceanography 24, 130-141. doi: 10.5670/oceanog.2011.10

Carlson, J., Wiley, T., and Smith, K. (2013). Pristis pectinata. The IUCN Red list of threatened species, 2013: e.T1. doi: 10.2305/IUCN.UK.20131.RLTS.T18175A43398238.en

Clark, T. B. (2010). Abundance, Home Range and Movement Patterns of Manta Rays (Manta alfredi, M. birostris) in Hawaii. Ph.D. thesis, University of Hawaii.

Compagno, L. J. V., and Last, P. R. (1999). Mobulidae. FAO species identification guide for fishery purposes. Living Mar. Resour. West. Cent. Pacific 3, 1524-1529.

\section{FUNDING}

This work was partially supported by PADI Foundation, Conservation Sew Mates and QiRetreats. CR was supported by two private trusts.

\section{ACKNOWLEDGMENTS}

We would like to thank all staff and volunteers of Large Marine Vertebrates Research Institute Philippines for their help with data collection, Nicholas K. Dulvy (Department of Biological Sciences-Simon Fraser University) for his useful comments, Ana Filipa Sobral (IMAR-University of Azores) for her communication, Dr. Jo Marie Acebes (Balyena.org), and Maita Verdote for their support, advice and shared information during the mobulid fishery monitoring project in Bohol, as well as Zerlina Leung (Conservation Sew Mates) and Angie Lim (QiRetreats) for their support. This work would not have been possible without the collaboration of the fishers from Jagna, the support of the Department of Agriculture-Bureau of Fisheries and Aquatic Resources Region 7, the Department of Environment and Natural Resources Region 7, the Province of Bohol, the Bohol Environmental Management Office and the Local Government Unit of Jagna (Bohol). We thank the Editor and the Reviewers for their comments and edits on our manuscript.

Cortés, E. (2000). Life history patterns and correlations in sharks. Rev. Fish. Sci. 8, 299-344. doi: 10.1080/10408340308951115

Cortés, E. (2002). Incorporating uncertainty into demographic modeling: application to shark populations and their conservation. Conserv. Biol. 16, 1048-1062. doi: 10.1046/j.1523-1739.2002.00423.x

Couturier, L. I. E., Marshall, A. D., Jaine, F. R. A., Kashiwagi, T., Pierce, S. J., Townsend, K. A., et al. (2012). Biology, ecology and conservation of the Mobulidae. J. Fish Biol. 80, 1075-1119. doi: 10.1111/j.1095-8649.2012.03 264.x

Croll, D. A., Dewar, H., Dulvy, N. K., Fernando, D., Francis, M. P., Galván-Magaña, F., et al. (2015). Vulnerabilities and fisheries impacts: the uncertain future of manta and devil rays. Aquat. Conserv. 26, 562-575. doi: 10.1002/aqc.2591

Cuevas-Zimbrón, E., Sosa-Nishizaki, O., Pérez-Jiménez, J., and O’Sullivan, J. B. (2013). An analysis of the feasibility of using caudal vertebrae for ageing the spinetail devilray, Mobula japanica (Müller and Henle, 1841). Environ. Biol. Fish. 96, 907-914. doi: 10.1007/s10641-0120086-2

Deakos, M. H., Baker, J. D., and Bejder, L. (2011). Characteristics of a manta ray Manta alfredi population off Maui, Hawaii, and implications for management. Mar. Ecol. Prog. Ser. 429, 245-260. doi: 10.3354/meps09085

Dulvy, N. K., Baum, J. K., Clarke, S., Compagno, L. J. V., Cortés, E., Domingo, A., et al. (2008). You can swim but you can't hide: the global status and conservation of oceanic pelagic sharks and rays. Aquat. Conserv. 18, 459-482. doi: 10.1002/ aqc. 975

Dulvy, N. K., Fowler, S. L., Musick, J. A., Cavanagh, R. D., Kyne, P. M., Harrison, L. R., et al. (2014a). Extinction risk and conservation of the world's sharks and rays. Elife 3:e00590. doi: 10.7554/eLife.00590.001

Dulvy, N. K., Pardo, S. A., Simpfendorfer, C. A., and Carlson, J. K. (2014b). Diagnosing the dangerous demography of manta rays using life history theory. Peer J 2:e400. doi: 10.7717/peerj.400

Fisher, R. A. (2010). Life History, Trophic Ecology, and Prey Handling by Cownose Ray, Rhinoptera Bonasus, from Chesapeake Bay. NOAA final report 
(NA07NMF4570324) Grant No. 713031 (No. 2010-20). VIMS Marine Resource Report, 98.

Fowler, S. L., Reed, T. M., and Dipper, F. A. (2002). "Elasmobranch biodiversity, conservation and management," in Proceedings of the International Seminar and Workshop (Sabah).

Goodwin, N. B., Dulvy, N. K., and Reynolds, J. D. (2002). Life-history correlates of the evolution of live bearing in fishes. Philos. Trans. R. Soc. Lond. 357, 259-267. doi: $10.1098 /$ rstb.2001.0958

Gordon, A. L., Sprintall, J., and Field, A. (2011). Regional oceanography of the Philippines Archipelago. Oceanography 24, 162-173. doi: 10.5670/ oceanog.2011.65

Graham, R. T., Witt, M. J., Castellanos, D. W., Remolina, F., Maxwell, S., Godley, B. J., et al. (2012). Satellite tracking of manta rays highlights challenges to their conservation. PLoS ONE 7:e36834. doi: 10.1371/journal.pone.0036834

Harry, A. V., Tobin, A., and Simpfendorfer, C. A. (2013). Age, growth and reproductive biology of the spot-tail shark, Carcharhinus sorrah, and the Australian blacktip shark, C. tilstoni, from the great barrier reef world heritage area, north-eastern Australia. Mar. Freshw. Res. 64, 277-293. doi: $10.1071 / \mathrm{mf} 12142$

Homma, K., Maruyama, T., Itoh, T., Ishihara, H., and Uchida, S. (1997). "Biology of the manta ray, Manta birostris Walbaum," in The Indo-Pacific, 5th Indo-Pac. Fish Conference (Noumea), 209-216.

ICES (2008). Report of the Workshop on Maturity Ogive Estimation for Stock Assessment (WKMOG). ICES CM2008/ACOM, 33.

ICES (2013). Report of the Workshop on Sexual Maturity Staging of Elasmobranchs (WKMSEL). ICES CM 2012/ACOM, 59.

Jaine, F. R. A., Rohner, C. A., Weeks, S. J., Couturier, L. I. E., Bennett, M. B., Townsend, K. A., et al. (2014). Movements and habitat use of reef manta rays off eastern Australia: offshore excursions, deep diving and eddy affinity revealed by satellite telemetry. Mar. Ecol. Prog. Ser. 510, 73-86. doi: 10.3354/meps10910

Marshall, A., Bennett, M. B., Kodja, G., Hinojosa-Alvarez, S., Galvan-Magana, F., Harding, M., et al. (2011b). Manta birostris. The IUCN Red List of Threatened Species, 2011: e.T1. doi: 10.2305/IUCN.UK.2011-2.RLTS.T198921A9108067.en

Marshall, A. D., and Bennett, M. B. (2010). Reproductive ecology of the reef manta ray Manta alfredi in southern Mozambique. J. Fish Biol. 77, 169-190. doi: 10.1111/j.1095-8649.2010.02669.x

Marshall, A. D., Compago, L. J. V., and Bennett, M. B. (2009). Redescription of the genus Manta with resurrection of Manta alfredi (Krefft, 1868) (Chondrichthyes; Myliobatoidei; Mobulidae). Zootaxa 2301, 1-28. doi: 10.5281/zenodo.191734

Marshall, A. D., Dudgeon, C. L., and Bennett, M. B. (2011a). Size and structure of a photographically identified population of manta rays Manta alfredi in southern Mozambique. Mar. Biol. 158, 1111-1124. doi: 10.1007/s00227-011-1634-6

Marshall, A. D., Pierce, S. J., and Bennett, M. B. (2008). Morphological measurements of manta rays (Manta birostris) with a description of a foetus from the east coast of Southern Africa. Zootaxa 1717, 24-30.

Mejía-Falla, P. A., Cortés, E., Navia, A. F., and Zapata, F. A. (2014). Age and growth of the round stingray Urotrygon rogersi, a particularly fast-growing and shortlived elasmobranch. PLoS ONE 9:e96077. doi: 10.1371/journal.pone.0096077

Mollet, H. F., and Cailliet, G. M. (2002). Comparative population demography of elasmobranchs using life history tables, Leslie matrices and stage-based matrix models. Mar. Freshw. Res. 53, 503-516. doi: 10.1071/mf01083

Mundy-Taylor, V., Crook, V., Foster, S., Fowler, S., Sant, G., and Rice, J. (2014). CITES Non-Detriment Findings Guidance for Shark Species - 2nd Revised Version a Framework to Assist Authorities in Making Non-Detriment Nindings (NDFs) for Species Listed in CITES Appendix, I. I. Report prepared for the Germany Federal Agency for Nature Conservation, Bundesamt für Naturschutz, BfN.

Musick, J. A., and Bonfil, R. (2004). Elasmobranch Fisheries Management Techniques. FAO Fisheries.

Notarbartolo-Di-Sciara, G. (1987). A revisionary study of the genus Mobula Rafinesque 1810 (Chondrichthyes, Mobulidae) with the description of a new species. Zool. J. Linn. Soc. 91, 1-91. doi: 10.1111/j.1096-3642.1987.tb01723.x

Notarbartolo-Di-Sciara, G. (1988). Natural history of the rays of the genus Mobula in the Gulf of California. Fish. Bull. 86, 45-66.

Nozu, R., Murakumo, K., Matsumoto, R., Matsumoto, Y., Yano, N., Nakamura, M., et al. (2017). High-resolution monitoring from birth to sexual maturity of a male reef manta ray, Mobula alfredi, held in captivity for 7 years: changes in external morphology, behavior, and steroid hormones levels. BMC Zool. 2:14. doi: 10.1186/s40850-017-0023-0

Pardo, S. A., Kindsvater, H. K., Cuevas-Zimbrón, E., Sosa-Nishizaki, O., Pérez-Jiménez, J., and Dulvy, N. K. (2016a). Devil in the details: growth, productivity, and extinction risk of a data-sparse devil ray. Sci. Rep. 6:33745. doi: 10.1038/srep33745

Pardo, S. A., Kindsvater, H. K., Reynolds, J. D., and Dulvy, N. K. (2016b). Maximum intrinsic rate of population increase in sharks, rays, and chimaeras: the importance of survival to maturity. Can. J. Fish. Aquat. Sci. 73, 1159-1163. doi: 10.1139/cjfas-2016-0069

Pardo, S. A., Walls, R. H. L., and Bigman, J. S. (2016c). Mobula tarapacana. The IUCN Red List of Threatened Species, 2016:eT6. doi: 10.2305/iucn.uk.20161.rlts.t60199a3091224.en

Pardo, S. A., Cooper, A. B., Reynolds, J. D., and Dulvy, N. K. (2018). Quantifying the known unknowns: estimating maximum intrinsic rate of population increase in the face of uncertainty. ICES J. Mar. Sci. 75, 953-963. doi: $10.1093 /$ icesjms/fsx 220

Pierce, S. J., and Norman, B. (2016). Rhincodon typus. The IUCN Red List of Threatened Species, 2016: e.T1. doi: 10.2305/IUCN.UK.2016-1.RLTS.T19488A2365291.en

Pierce, S. J., Pardo, S. A., and Bennett, M. B. (2009). Reproduction of the blue-spotted maskray Neotrygon kuhlii (Myliobatoidei: Dasyatidae) in south-east Queensland, Australia. J. Fish Biol. 74, 1291-1308. doi: 10.1111/j.1095-8649.2009.02202.x

Rambahiniarison, J. M., Araujo, G., Lamoste, M. J., Labaja, J., Snow, S., and Ponzo, A. (2016). First records of the reef manta ray Manta alfredi in the Bohol Sea, Philippines, and its implication for conservation. J. Asia-Pacific Biodiv. 9, 1-5. doi: 10.1016/j.japb.2016.07.002

Rambahiniarison, J., Lamoste, M. J., Rohner, C. A., Araujo, G., Murray, R., Snow, S., et al. (2018). Life History, Growth, and Reproductive Biology of Four Mobulid Species in the Bohol Sea, Philippines. Dryad Digital Repository. doi: 10.5061/dryad.f3bm7

Rayos, C. J., Santos, M. D., and Barut, N. C. (2012). Devil ray resources in Bohol Sea, Philippines. Fish People 10, 19-23.

Republic of the Philippines. (1998). Department of Agriculture: Fisheries Administrative Order no. 193. Available online at: https://www.bfar.da.gov.ph/ LAW?fi=335\#post

Republic of the Philippines (2015). Congress of the Philippines, Metro Manila. Republic Act 10654. Available online at https:/www.ofdc.org.tw/components/ Editor/webs/files/Republic\%20Act\%20No\%2010654.pdf

Rohner, C. A., Burgess, K. B., Rambahiniarison, J. M., Stewart, J. D., Ponzo, A., and Richardson, A. J. (2017). Mobulid rays feed on euphausiids in the Bohol Sea. $R$. Soc. Open Sci. 4:161060. doi: 10.1098/rsos.161060

Rohner, C. A., Pierce, S. J., Marshall, A. D., Weeks, S. J., Bennett, M. B., and Richardson, A. J. (2013). Trends in sightings and environmental influences on a coastal aggregation of manta rays and whale sharks. Mar. Ecol. Prog. Ser. 482, 153-168. doi: 10.3354/meps 10290

Simpfendorfer, C. A. (2000). Predicting population recovery rates for endangered Western Atlantic sawfishes using demographic analysis. Environ. Biol. Fishes 58, 371-377. doi: 10.1023/A:1007675111597

Simpfendorfer, C. A., and Wetherbee, B. (2015). Shark and ray life history. Mar. Freshwater Res. 66, i-ii. doi: 10.1071/mfv66n4_ed

Sims, D. W. (2003). Tractable models for testing theories about natural strategies: foraging behaviour and habitat selection of free-ranging sharks. J. Fish Biol. 63, 53-73. doi: 10.1046/j.1095-8649.2003.00207.x

Stevens, G. (2011). Field Guide to the Identification of Mobulid Rays (Mobulidae): Indo-West Pacific. The Manta Trus.

Stevens, J. D., Bonfil, R., Dulvy, N. K., and Walker, P. A. (2000). The effects of fishing on sharks, rays, and chimaeras (chondrichthyans), and the implications for marine ecosystems. ICES J. Mar. Sci. 57, 476-494. doi: 10.1006/jmsc.2000.0724

Stewart, J. D., Beale, C. S., Fernando, D., Sianipar, A. B., Burton, R. S., Semmens, B. X., et al. (2016). Spatial ecology and conservation of Manta birostris in the Indo-Pacific. Biol. Conserv. 200, 178-183. doi: 10.1016/j.biocon.2016.05.016

Stewart, J. D., Rohner, C. A., Araujo, G., Avila, J., Fernando, D., Forsberg, K., et al. (2017). Trophic overlap in mobulid rays: insights from stable isotope analysis. Mar. Ecol. Prog. Ser. 580, 131-151. doi: 10.3354/meps12304 MARINE 
Walls, R. H. L., Pardo, S. A., Bigman, J. S., Clark, T. B., Smith, W. D., and Bizzarro, J. (2016). Mobula thurstoni. The IUCN Red List of Threatened Species, 2016:e.T6. doi: 10.2305/IUCN.UK.2016-1.RLTS.T60200A3091468.en

White, W. T., Clark, T. B., Smith, W. D., and Bizzarro, J. J. (2006a). Mobula japanica. The IUCN Red List of Threatened Species, 2006:eT4. doi: 10.2305/IUCN.UK.2006.RLTS.T41833A10576180.en

White, W. T., Giles, J., Dharmadi, and Potter, I. C. (2006b). Data on the bycatch fishery and reproductive biology of mobulid rays (Myliobatiformes) in Indonesia. Fish. Res. 82, 65-73. doi: 10.1016/j.fishres.2006. 08.008

White, W. T., Corrigan, S., Yang, L. E. I., Henderson, A. C., Bazinet, A. L., Swofford, D. L., et al. (2017). Phylogeny of the manta and devil rays (Chondrichthyes: Mobulidae), with an updated taxonomic arrangement for the family. Zool. J. Linnean Soc. 182, 50-75. doi: 10.1093/zoolinnean/ zlx018
Yano, K., Sato, F., and Takahashi, T. (1999). Observations of mating behavior of the manta ray, Manta birostris, at the Ogasawara Islands, Japan. Ichthyol. Res. 46, 289-296. doi: 10.1007/BF02678515

Conflict of Interest Statement: The authors declare that the research was conducted in the absence of any commercial or financial relationships that could be construed as a potential conflict of interest.

Copyright (C) 2018 Rambahiniarison, Lamoste, Rohner, Murray, Snow, Labaja, Araujo and Ponzo. This is an open-access article distributed under the terms of the Creative Commons Attribution License (CC BY). The use, distribution or reproduction in other forums is permitted, provided the original author(s) and the copyright owner(s) are credited and that the original publication in this journal is cited, in accordance with accepted academic practice. No use, distribution or reproduction is permitted which does not comply with these terms. 